\title{
Surviving the COVID-19 Pandemic: Hoteliers' Resilience
}

\section{Gusti Ayu Putu Wita Indrayani ${ }^{1 *}$}

${ }^{1}$ Bali Tourism Polytechnic, Badung, Indonesia

\section{ART I CLE I N F O}

\section{Article history:}

Received Auguts 12, 2021

Revised August 13, 2021

Accepted October 20, 2021

Available online November 25, 2021

\section{Keywords:}

Covid-19 Pandemic, HR Practice, Hospitality, Survival Strategy, Entrepreneurship

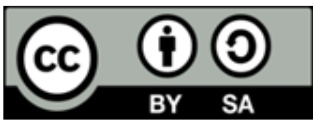

This is an open access article under the CC BY-SA license.

Copyright (C) 2021 by Author. Published by Universitas Pendidikan Ganesha.

\begin{abstract}
A B S T R A C T
The COVID-19 pandemic has impacted the entire world. The industry experienced a significant downturn. Unprecedented global travel restrictions and government instructions to stay at home are causing the most significant disruption to the global economy. Many hotel employees have been laid off both formally and informally in the current pandemic situation. It results in people losing their income. This study aims to analyze the strategies used by human resources in the tourism sector, especially hospitality, which has been affected by the COVID-19 pandemic to survive in the middle. This study uses an approach using descriptive analysis. Informants who previously worked in the tourism sector and made Covid19 adapt and implement various strategies simultaneously to survive and be resilient during the pandemic. The methods used to collect data are questionnaires and interviews. The analysis in this study was conducted using a qualitative descriptive method. The research findings reveal the dominance of the strategies adopted by key informants. Entrepreneurial orientation, motivation and effort are the most prominent approaches in an active strategy to solve problems. Former hoteliers gain resilience to survive during the pandemic by empowering skills from past work experience in star hotels and conducting retraining programs through government policies. Human resources in the tourism sector are expected to foster social-based entrepreneurship or opportunities and needs-based entrepreneurship so that businesses remain stable in the future.
\end{abstract}

\section{INTRODUCTION}

Since its discovery in Wuhan, China, in December 2019, the Coronavirus (COVID-19) has had a worldwide effect (Hong et al., 2021; Singhal, 2020; Tang et al., 2021). The tourism industry is under pressure as a result of a large decline in international visitor arrivals, a decrease in bookings, and enormous cancellations of bookings (Abbas, Mubeen, et al., 2021; Paramita \& Putra, 2020). Tourism is a laborintensive business that employs millions of people; thus 13 million people were employed in this sector in Indonesia as of January 2020. This sector also contributes a significant amount of foreign exchange. In early 2020, the tourism sector generated 280 trillion rupiahs in foreign exchange (Adyaharjanti \& Hartono, 2020). Unprecedented global travel restrictions and government instructions to stay at home resulted in the greatest disruption to the global economy since World War II (Gössling et al., 2020). In many nations, the virus impacts nearly every aspect of the hospitality value chain. The impact of event cancellations, closures of lodging services, and tourist attractions is felt immediately on other sides of the hospitality supply chain, such as food and beverage services, laundry, transportation, and flights (Mafimisebi et al., 2021; Sharma et al., 2021; Singh et al., 2021). The Indonesian Hotel and Restaurant Association (PHRI) reported 1,542 hotel units halted in 31 provinces in Indonesia as of April 2020, mainly attributed to the COVID-19 pandemic (Inasito \& Rosdiana, 2021). To brace for a pandemic, hotels that are still operating have developed a variety of survival strategies, including cost-reduction, layoffs, tightening profit margins, and cash flow management (Škare et al., 2021; Yin \& Ni, 2021).

Several prior empirical studies have been undertaken to uncover commercial businesses' efforts to survive and emerge from the situation of crisis. According to one of the studies on Malaysian accommodation development companies, distressed companies' survival strategies included asset divestiture to boost cash flow, refinancing liabilities, postponing the launch of new projects, and reducing their personnel (Chan \& Abdul-Aziz, 2017). Meanwhile, non-stressed companies adopt growth strategies such as purchasing property for development, focusing on high-end goods, and vertically integrating and diversifying (Chan \& Abdul-Aziz, 2017). In the context of a pandemic that is currently confronting all 
components of the hospitality industry system chain, a similar survival strategy has also been implemented in an organizational setting that emphasizes business innovation, both in the marketing field and in operations (Breier et al., 2021; Wang et al., 2020). However, earlier work of survival or coping strategies has been focused on the organizational level. There has been a lack of research and limited study conducted to investigate the impact of the pandemic on individuals, particularly those working in the hospitality industry. As it is broadly known, hospitality is a labour-intensive and human-centered sector. In the present pandemic circumstances, which affect all sectors and even the smallest elements, many hotel employees are laid off both formally and informally. According to deprivation theory, employment has both explicit (desired outcomes such as money) and latent consequences (undesired outcomes such as status, identity, social relations, and time structure), and job loss implies losing both. Moreover, according to the literature, unemployment has significant economic and social implications (Blau et al., 2013; Sharabi et al., 2019).

The consequence of the COVID-19 attack has led to a surge in tourism workers layoffs in Badung. Even looking at the facts on the ground, most of the hotel businesses in Bali have been closed since early April 2020. The closure of hundreds of hotels in Bali certainly impacts the lives of thousands of employees who have been working in the accommodation sector. As of April 13, 2020, the number of laid-off employees has reached 800, and 46,000 employees have been laid off (Hadi et al., 2021). With the increasing numbers of star hotel staff getting laid off or pushed to take unpaid leave as a result of the pandemic, they must be able to think creatively and innovatively to survive. Because of the financial difficulties of fulfilling their daily requirements, hoteliers or ex-hoteliers who are married encounter an even more difficult situation. One of the phenomena in the recent situation is the emerging number of hotel employees shifting professions to become entrepreneurs in other sectors using online platforms (social media) such as WhatsApp, Instagram, Facebook, and Twitter.

Survival strategies for resisting economic crises can be carried out in a variety of ways. The survival strategy is fascinating to examine because it provides insight into how to manage and utilize the resources and capital assets acquired via specific activities. Survival strategy is as a sequence of behaviours chosen by socially and economically deprived people and households based on the standard (Abbas, Azizi, et al., 2021; Shakerian et al., 2016). Survival strategy as a person's capacity to use a set of methods to overcome various difficulties in his life; this problem-handling strategy is the ability of all family members to manage their assets. There are three types of survival strategies: active strategies, passive strategies, and network strategies (Díaz-López et al., 2022; Qiu \& Jiang, 2022). The purpose of this study is to analyze the strategies used by hotel personnel (hotel managers) who previously worked in five-star hotels or have been affected by COVID-19 to survive in this pandemic condition. This study contributes to the literature by emphasizing individual resiliency to confront unprecedented crises from the perspective of social and human competencies. This is the empirical gap of previous studies that need to be explored to enhance the existing literature. The survival strategies implemented by skilled hoteliers to build resiliency during the pandemic crisis are a reflection of the social employment conditions in the Badung Regency, particularly in the hospitality industry.

\section{METHODS}

To achieve the purpose of the study, this research adopts an interpretive paradigm using qualitative analysis. Using the grounded theory of Individual Survival Strategy, the research design is a cross-sectional study a form of observational research that examines data from a population, or a representative subset of a population, at a specific time frame. The population in this study were hotel employees in Badung Regency who were impacted by COVID-19, whether they were laid off or did not get sufficient salaries. Because the number of employees impacted by COVID-19 cannot be estimated with precision, the population in this study is considerable. Non-probability sampling was employed in this study, which is a sampling approach that gives various possibilities or opportunities for each element or member of the population to participate. Data collection in a study must be done properly, deliberately, and meticulously so that the data obtained is relevant to the research topic. In this study, the questionnaire was scored ordinarily using a Likert scale. Using a Likert scale will make it easier for participants to comprehend and fill out the form, making the process more efficient. The questionnaire question items were formulated through the application of three survival strategies: active strategy, passive strategy, and network strategy.

Data collection methods used in this study were 1) Questionnaires, namely data collection techniques performed by giving several structured written questions to research respondents regarding their responses to various variables studied in this study; and 2) Interviews, namely data collection by conducting in-depth questions and answers with research respondents to obtain more accurate and complete data. The analysis in this study was conducted using a qualitative descriptive method, which relates to three survival strategies, which were carried out through three phases of the flow, namely: data 
reduction, data presentation, and conclusion or verification (Miles \& Huberman, 2007). In qualitative descriptive-analytic studies, the features of the observed phenomenon are identified, or the possible connection between two or more occurrences is explored (Miles \& Huberman, 2007). Furthermore, descriptive analysis involves the interpretation of data and correlations identified in the research.

\section{RESULTS AND DISCUSSIONS}

\section{Results}

This section seeks to respond to the issue formulation and research objectives, namely, to expose and explain information relevant to the strategies used by human resources in the hospitality industry in various types of businesses to survive the COVID-19 pandemic. This current study data was gathered using questionnaires and field observations, which were then supplemented with interviews with numerous key informants who were relevant to the study's locus. In addition, the data was examined employing qualitative descriptive-analytic methodologies in three stages: data reduction, data presentation, and generating conclusions or verification. A set of questions or questionnaires in digital form (Google form) are delivered to target participants through email, WhatsApp, Facebook, Instagram, and other social media platforms. This digital questionnaire is divided into three sections: an overview of the varieties of businesses affected by Covid, participant characteristics or profiles, and the strategies they employ to survive a pandemic. The survival strategy relates to the previously mentioned theory, which includes Active Strategy, Passive Strategy, and Network Strategy.

The majority, 60.3 percent, of the 146 participants in the research came from the type of accommodation industry. Hotels, villas, homestays, and other enterprises with identical business activities are included in this business category. This conclusion is highly significant, because the lodging company plays a vital function as the major infrastructure in the tourism pillar, and it is sometimes admitted that the accommodation business is the principal tourism superstructure. The underlying premise is that when there is a movement of people traveling to a destination, the presence of an accommodation company in that destination has a significant effect on purchase decisions and tourist perceptions. This accommodation sector, particularly in Bali, is critical to the development of tourism, as seen by the hotel growth trend, which is good. As a result, during the Covid19 Pandemic, the lodging industry, which is the backbone of Bali's tourism, was one of the most devastated and experienced a significant decline.

Aside from the accommodation business, other fields built as a support system for Bali tourism were also impacted, including culinary businesses (restaurants, cafes, bars, restaurants), travel and event agencies (travel agents, tour operators, event organizers), the transportation business (including tourist vehicle rental), and other recreational businesses (spa, salon, water sports). The fall in the room occupancy rate (TPK) in Bali during the early days of the pandemic was quite severe and significant, reaching a low of zero percent.bApart from the accommodation business, businesses in other fields built as a supporting system for Bali tourism were also affected, such as culinary businesses (restaurants, cafes, bars, restaurants), travel and event agencies (travel agents, tour operators, event organizers), transportation business (including tourist vehicle rental), and other recreational businesses (spa, salon, water sport). The decline in the Room Occupancy Rate (TPK) in Bali during the early days of the pandemic had a very drastic and significant drop to its lowest point, which is zero percent. This is due to the extensive cancellation of orders in reaction to people's demand for social/physical distance, avoidance of crowds and public areas, and heeding the government's travel advisories. As a result, other businesses that support the tourism sector earn from a multiplier effect.

Badung Regency offers the most lodging companies and the largest variety when compared to other districts in Bali, particularly in the South Badung area (Kuta, Nusa Dua, Legian, and Seminyak) since it is one of Bali's most popular tourist destinations for investors. The largest source of potential revenue in Badung Regency is Hotel and Restaurant Revenue (PHR), thus it is fair to say that Badung Regency is the "home" of the majority of Bali's lodging companies. As a result, 70.5 percent of participants in this survey worked for tourist companies in Badung Regency, followed by Denpasar City (14.4 percent) and Gianyar Regency (14.4 percent). To survive this pandemic, tourism-related firms must react to situations strategically. According to the conclusions of interviews with the general managers of hotels in the Ubud and Kuta districts, both of them stated that during this uncertain pandemic situation, the company's priority was not on seeking development (profit), but on attempting to survive (survival). This survival mode implies that the firm must be able to reduce all sorts of expenditures to a bare minimum, as well as manage human resources, including quantity and compensation because the financing side is under the company's control, but the income/profit side is very unpredictable.

According to observations and interviews with General Hotels in Kuta and Ubud, a retrenchment strategy is the most prevalent and practical method to be applied during this pandemic. Retrenchment 
occurs when a firm restructures its strategy to cope with all scenarios by lowering expenses and assets to reverse a decline in sales and earnings (David and David, 2017). This method is also known as the Reorganization Strategy or the Turnaround Strategy. Retrenchment might entail a variety of operations, such as selling hotel assets to obtain the necessary funds, decreasing product lines, shutting down marginal companies, reducing the number of workers, and implementing an expenditure management system. From the data that has been collected using various data collection techniques, it is known that 52.7 percent of participants in this study are required to take unpaid leave (Unpaid Leaves) by the company where they work. The giving of Unpaid Leaves has both positive and negative sides from the employee's point of view. Viewed from the positive side, employees still have the status of workers at the company even though they are not paid at all so that when conditions gradually improve, the company will recall their employees. But on the other hand, the company does not provide a certain time until when they have to wait to work again so that employees have high job insecurity for their future. After being tracked down, this one participant worked on a business that was not directly related to tourism.

According to the data obtained using various data collection methodologies, 52.7 percent of the participants in this study were compelled by their employers to take unpaid leave. Unpaid Leave has both beneficial and negative aspects from the employee's perspective. From a positive standpoint, employees retain their position as employees of the firm even though they are not paid, so that when situations gradually recover, the company will reinstate their employees. On the other hand, the company does not specify how long employees should wait before returning to work, resulting in significant job insecurity in the future. During the pandemic, hotels lowered salaries and benefits by 34.9 percent and laid off 33.6 percent of their employees. A discussion with one of the informants, who is still working at a star hotel in the Kuta region, revealed that he has not received his proper salary since the beginning of the outbreak. The total number of pay deductions made by the company each month in phases. Beginning with a $20 \%$ reduction in April and May 2020, the nominal take-home pay received at that time was only $80 \%$ of the entire salary and allowances. Informants were only paid based on attendance that was strictly scheduled by the company up to the time of the interviews. Many staff were allowed to resign as a result of the pandemic. In this research, 49 out of a total of 146 participants (33.6 percent) indicated that companies laid off themselves so that entrepreneurship is the most likely option for them to survive.

\section{Discussion}

A survival strategy is a set of activities that are intentionally selected by underprivileged people and households. This technique can be used to try to increase income from other sources or to cut expenditures by lowering the number and quality of goods or services (Abbas, Azizi, et al., 2021; Shakerian et al., 2016). Individuals' strategies are affected by their status in society's structure, belief system, and social networks, as well as their competence in mobilizing existing resources, skill level, asset ownership, kind of employment, gender status, and personal motivation (Armstrong \& Fischer, 2020; Deschênes et al., 2020). According to the study's findings, the most common active strategy used amongst tourist personnel is income diversification or the search for additional income through side employment. According to the questionnaire respondents, having specific skills may lead to initiative and drive, as well as opening up chances for entrepreneurial ventures to thrive amid the pandemic. Forty-eight percent of respondents indicated that they have skills that can be used to start new businesses. The remaining 36.5 percent did not expressly state what skills they have that may be employed as a source of income in this circumstance. A study found comparable outcomes for tourist employees who planned to shift jobs completely during Egypt's time of political turbulence (Perles-Ribes et al., 2016; Saad \& Elshaer, 2017). Moving into another industry appeared as one of the important solutions in this specific context, as the current study was performed at a moment of the tourism crisis (Utkarsh \& Sigala, 2021; Yang et al., 2021). Problem-focused solutions such as job searches, retraining, and geographical relocation are consistent with the research, but in the context of a sectoral crisis, shifting into another sector is recommended as a new strategy.

Furthermore, it was found that only 58.1 percent used their skills to open additional businesses and 59.5 percent had realized it in the form of a real business. Meanwhile, the remaining 41.9 percent chose not to open additional businesses. When explored deeper, the reason why they chose not to open an additional business was that they needed a lot of capital to open an additional business and many of their acquaintances had done it first, so they felt the additional income they got was not worth the extra effort they spent to make it happen. In this study, conducting flexible work was discovered and recommended as one of the active strategies utilized by tourism and hospitality professionals. An earlier study with jobless white-collar employees in Turkey discovered that short-term, temporary, low-skilled, project-based work is a possible solution to make a living (Afonso-Rodríguez, 2017). The form of diversification undertaken by tourism human resources is trading or selling by utilizing digital platforms, such as social media such as Instagram, Facebook, Whatsapp, marketplace, and others (Arora et al., 2021; Dwivedi et al., 2021). The 
selected distribution channels through social media are considered very relevant to the current conditions, where there are programs for limiting social distancing, easy accessibility, and do not require too high initial capital to open a stall. The types of products traded vary, but the majority are related to hygiene and sanitation items that are much needed during this pandemic, such as masks, face shields, tissues, sanitizers, and cleaners. Besides, which are also widely traded are perishable products, frozen food products, and prepared or processed foods. This business was started and managed with family and colleagues.

This finding is in line with previous studies conducted to identify the active strategy implemented by individuals during a crisis. One of the most common approaches is to empower and optimize prior job experience capabilities. Respondents were able to build resilience throughout the epidemic because of the abilities they gained while working in hotels. These abilities may be utilized to foster company innovation and promote entrepreneurial endeavours. This conclusion is consistent with earlier studies, which found that innovation is one of the greatest ways to withstand disruptions that interrupt the ordinary way of life (Bisnis et al., 2020; Yi et al., 2022). From the demographic profiles of respondents described in the previous section, especially concerning their educational backgrounds, most of whom are diploma graduates, it can be concluded that the selection of active strategies is very relevant to be carried out today. This is because the respondents have already acquired formal skills during college. Also, because the majority of respondents are still very young so that morale is still relatively high, entrepreneurial motivation tends to be at a fairly high level. Entrepreneurship is one way of applying value and innovation to the respondent's business. Social challenges (such as poverty, health, education, and environmental difficulties) experienced by many nations across the world, including Indonesia, can be solved through social entrepreneurship initiatives. The objective of social entrepreneurship is to achieve positive social change, such as the realization of the welfare of the community. The procedure for accomplishing this aim is none other than the application of entrepreneurial principles. It is important to note that resilience is a component of human capital (Brewton et al., 2010; Musavengane \& Kloppers, 2020). Human capital can include specific skills and the study shows how entrepreneurial skills can be cultivated through the ownership of these specific skills.

The passive strategy that is usually carried out by tourism human resources who are the unit of analysis in this study is to get used to living frugally because most of the respondents expressed their concern that they could not fulfill their basic needs during this pandemic, as much as 83.1 percent. The underlying point is very clear. The Covid-19 pandemic is putting enormous pressure and shocks on the tourism industry which is very dependent and relies on the movement of people from one place to another (Abbas, Mubeen, et al., 2021; Singh et al., 2021; Soliku et al., 2021). With social distancing restrictions and restrictions on large gatherings, tourism activities cannot run as they used to. Covid-19, which was a health crisis, has now become a global financial crisis that has left many countries on the brink of an alarming recession (Gössling et al., 2020; Sharma et al., 2021). To make matters worse, no one can predict how long this difficult time will last. Therefore, the tourism human resources interviewed stated that they managed finances strictly, whether they were married or not. In general, the best approach to saving money is to prioritize the allocation of cash to fundamental or essential requirements such as clothes, food, and housing (Mafimisebi et al., 2021; Škare et al., 2021; Yin \& Ni, 2021). One informant, who is married and has one child, indicated that he prefers to cook for himself rather than buy ready-made processed meals for his daily food needs. Food costs can be minimized by cooking according to the needs of the family every day. Furthermore, some informants used various techniques to reduce the cost of living, one of which is delaying the payment of obligations (debts) by submitting them to the bank for a deferral of monthly instalments. Although the delay in this payment spans from three months to a year, it is shown to be highly beneficial in minimizing their living expenses.

In terms of investment, only 25.7 percent of participants have businesses to invest, either small or medium scale, while the remaining 74.3 percent stated that they do not have the intention to do so as can be seen in Figure 5.9. Participants who choose to invest are those who still have idle savings so that they don't interfere with their daily lives. The results of the interview revealed that examples of investments made were crowdfunding and investment in gold whose value was more stable. Furthermore, it is known that as many as 28.4 percent of participants tried to set aside a small portion of their income to carry out their entertainment activities, the majority of which were carried out by participants who were not married. Looking back on their lives, respondents stated how insecurity and hard work were typical experiences. This study examines how hoteliers interpret market dynamics, global crises, and pandemics as external disruptions. Market shifts might be viewed as a deliberate element of regular competitive risks (Gössling et al., 2020; Williams \& Baláž, 2015). Disasters may be transformed into opportunities for revitalization and creativity. Returning to the same equilibrium as before the financial crisis caused by the Bali bombings in 2002 and 2005, responders have learned to bounce forward rather than backward and produce something new (Davoudi et al., 2012; Ko et al., 2010). Thus, this finding is consistent with previous research. 
The results showed that the financial assistance received from family or colleagues helped fulfill the needs of daily life. With the existence of assistance programs from the government, both central and regional governments, in the form of the distribution of the logistics of the nine basic food logistics that are distributed to families in need, it is also felt that they can ease the burden on the lives of participants. The results showed that only 17.6 percent of the total participants had applied for loans from banks or other sources of funding during the pandemic, while the majority of participants as many as 82.4 percent chose to stay with their remaining savings because of fears that they could not pay off their obligations if borrowing from the bank. Loans submitted by participants are generally submitted to Village Credit Institutions (LPD) in the area where they live due to low loan interest rates. Besides, based on interviews with several participants, the amount of loan proposed varies from 2 million to 25 million rupiahs. Participants realize that this loan is temporary and they also cannot always rely on assistance from other parties, both financial and non-financial assistance. Therefore, most of the participants showed an interest in taking courses or training to acquire additional skills that could be used to open their businesses. Some of the participants have tried to register themselves in the Pre-Work Program launched by the government. This program allows them to create new skills and resharpen their existing skills (retraining) which have been owned from their past working experience. Seeking financial and social assistance, as well as participating in community activity, are examples of passive strategies (Block \& Sandner, 2009; Karsavuran, 2020). Another support provider during the crisis is the family. Families provide both social and financial assistance, and they play an important role in mitigating the negative impacts of unemployment. Family members, most notably parents, assist the unemployed by offering pocket money, paying living expenses, and providing an opportunity to return to living with their parents. Parental assistance is provided for their unemployed children, regardless of gender, age, or marital status. Families impose their beliefs and standards in exchange for the assistance they offer, and they enforce their will on the unemployed as to what employment they will choose (Afonso-Rodríguez, 2017).

The majority of participants expressed their interest in continuing their business as much as 62.2 percent. The different motivations for entrepreneurial decisions influence the impact that a new venture might have on society and the economy. Currently, the entrepreneurial motivation carried out by tourism human resources is called need-based entrepreneurship (NEC). This type of entrepreneurship starts a business because of the 'impulse motive', as a way to compensate for the lack of other sources of work (Shane, 2009; Valdez \& Richardson, 2013). Needs-based entrepreneurship (NEC) is often associated with informal activities, unemployment, economic recession, and poverty (Gries \& Naude, 2011). Innovation through entrepreneurial motives could be the solution to gain resilience in this pandemic. Further research into the factors influencing employment in the tourist and hospitality sectors is needed and the findings reported in this study may be beneficial in creating new research questions (Baum et al., 2016). These findings enable a better understanding of job loss coping to survive and remain resilient in the pandemic. The findings of this study contribute to the literature on survival strategies for job loss coping by giving evidence from a specific setting. This research also contributes to the tourism crisis literature by focusing on employees who lost their jobs as "victims" of industry crises. Entrepreneurial motivations and efforts are the most salient approach in an active strategy to solve the problem of unemployment during the pandemic. Empowering the skills from past working experience in star hotels and doing retraining through a government program, ex-hoteliers gain resilience to survive.

\section{CONCLUSION}

The hoteliers affected by Covid-19 adopt multiple strategies simultaneously to survive and meet the basic needs of the family, namely: active strategy, passive strategy, and strategy network. Survival strategies found included job searching, changing careers, retraining, economic measures, casual work, social support, and recreational activities. Of the three strategies, the majority of participants applied more active strategies than other strategies. This is because, in terms of demographics, most of the participants are at a very productive age, namely under 40 years of age, and have a diploma education background, which is assumed by the participants to have basic skills that have the potential to be used as an entrepreneurial effort.

\section{REFERENCES}

Abbas, J., Azizi, M. R., Atlasi, R., Ziapour, A., Abbas, J., \& Naemi, R. (2021). Innovative human resource management strategies during the COVID-19 pandemic: A systematic narrative review approach. Heliyon, 7(6). https://doi.org/10.1016/j.heliyon.2021.e07233.

Abbas, J., Mubeen, R., Iorember, P. T., Raza, S., \& Mamirkulova, G. (2021). Exploring the impact of COVID-19 
on tourism: transformational potential and implications for a sustainable recovery of the travel and leisure industry. Current Research in Behavioral Sciences, 2. https://doi.org/10.1016/j.crbeha.2021.100033.

Adyaharjanti, A., \& Hartono, D. (2020). Dampak Pengeluaran Wisatawan Mancanegara terhadap Perekonomian Indonesia: Analisis Input Output Miyazawa. Jurnal Ekonomi Kuantitatif Terapan, 13(1). https://doi.org/10.24843/JEKT.2020.v13.i01.p02.

Afonso-Rodríguez, J. A. (2017). Evaluating the dynamics and impact of terrorist attacks on tourism and economic growth for Turkey. Journal of Policy Research in Tourism, Leisure and Events, 9(1). https://doi.org/10.1080/19407963.2016.1231196.

Armstrong, D. P., \& Fischer, S. L. (2020). Understanding individual differences in lifting mechanics: Do some people adopt motor control strategies that minimize biomechanical exposure. Human Movement Science, 74. https://doi.org/0.1016/j.humov.2020.102689.

Arora, A. S., Sivakumar, K., \& Pavlou, P. A. (2021). Social capacitance: Leveraging absorptive capacity in the age of social media. Journal of Business Research, 124. https://doi.org/10.1016/j.jbusres.2020.11.035.

Baum, T., Kralj, A., Robinson, R. N. S., \& Solnet, D. J. (2016). Tourism workforce research: A review, taxonomy and agenda. Annals of Tourism Research, 60. https://doi.org/10.1016/j.annals.2016.04.003.

Bisnis, J. M., Komara, B. D., Cahyo, H., \& Setiawan, B. (2020). Jalan Terjal UMKM dan Pedagang Kecil Bertahan di Tengah Pandemi Covid-19 dan Ancaman Krisis Ekonomi Global. Jurnal Manajemen Bisnis, 17(3). https://doi.org/10.38043/jmb.v17i3.2506.

Blau, G., Petrucci, T., \& McClendon, J. (2013). Correlates of life satisfaction and unemployment stigma and the impact of length of unemployment on a unique unemployed sample. Career Development International, 18(3). https://doi.org/10.1108/CDI-10-2012-0095.

Block, J., \& Sandner, P. (2009). Necessity and opportunity entrepreneurs and their duration in selfemployment: Evidence from German Micro data. Journal of Industry, Competition and Trade, 9(2). https://doi.org/10.1007/s10842-007-0029-3.

Breier, M., Kallmuenzer, A., Clauss, T., Gast, J., Kraus, S., \& Tiberius, V. (2021). The role of business model innovation in the hospitality industry during the COVID-19 crisis. International Journal of Hospitality Management, 92. https://doi.org/10.1016/j.ijhm.2020.102723.

Brewton, K. E., Danes, S. M., Stafford, K., \& Haynes, G. W. (2010). Determinants of rural and urban family firm resilience. Journal of Family Business Strategy, 1(3). https://doi.org/10.1016/j.jfbs.2010.08.003.

Chan, T. K., \& Abdul-Aziz, A. R. (2017). Financial performance and operating strategies of Malaysian property development companies during the global financial crisis. Journal of Financial Management of Property and Construction, 22(2). https://doi.org/10.1108/JFMPC-02-2016-0009.

Davoudi, S., Shaw, K., Haider, L. J., Quinlan, A. E., \& Peterson, G. D. (2012). Resilience: A Bridging Concept or a Dead End? "Reframing" Resilience: Challenges for Planning Theory and Practice Interacting Traps: Resilience Assessment of a Pasture Management System in Northern Afghanistan Urban Resilience: What Does it Mean in Planni. In Planning Theory and Practice, 13(2). https://doi.org/10.1080/14649357.2012.677124.

Deschênes, S., Dumas, C., \& Lambert, S. (2020). Household resources and individual strategies. World Development Perspectives, 135. https://doi.org/10.1016/j.worlddev.2020.105075.

Díaz-López, C., Serrano-Jiménez, A., Lizana, J., López-García, E., \& Molina-Huelva, M. (2022). Passive action strategies in schools: A scientific mapping towards eco-efficiency in educational buildings. Journal of Building Engineering, 45. https://doi.org/10.1016/j.jobe.2021.103598.

Dwivedi, Ismagilova, E., Hughes, D. L., Carlson, J., Filieri, R., \& Jacobson, J. (2021). Setting the future of digital and social media marketing research: Perspectives and research propositions. International Journal of Information Management, 51. https://doi.org/10.1016/j.ijinfomgt.2020.102168.

Gössling, S., Scott, D., \& Hall, C. M. (2020). Pandemics, tourism and global change: a rapid assessment of COVID-19. Journal of Sustainable Tourism, https://doi.org/10.1080/09669582.2020.1758708.

Gries, T., \& Naude, W. (2011). Entrepreneurship, Structural Change and a Global Economic Crisis. Entrepreneurship Research Journal, 1(3). https://doi.org/10.2202/2157-5665.1029.

Hadi, I. G. A. A., Sudiatmaka, K., Febrinayanti, K., \& Dantes. (2021). Pemenuhan Hak Dan Jaminan Pekerja Berdasarkan UU No. 11 Tahun 2020 Tentang Cipta Kerja Bagi Karyawan Hotel Di Badung. Proceeding Senadimas Undiksha.

Hong, J.-C., Lee, Y.-F., \& Ye, J.-H. (2021). Procrastination predicts online self-regulated learning and online learning ineffectiveness during the coronavirus lockdown. Personality and Individual Differences, 174, 110673. https://doi.org/10.1016/j.paid.2021.110673.

Inasito, D. O., \& Rosdiana, H. (2021). Kebijakan Pengaturan Pajak Hotel Dan Restoran Sebagai Sumber 
Pendapatan Daerah Dki Jakarta Di Tengah Pandemi Covid-19. Syntax Idea, 12(3).

Karsavuran, Z. (2020). Surviving a major crisis: the case of dismissed tourism and hospitality employees. Journal of Policy Research in Tourism, Leisure and Events, 1. https://doi.org/10.1080/19407963.2020.1787421.

Ko, C. H., Hsiao, S., Liu, G. C., Yen, J. Y., Yang, M. J., \& Yen, C. F. (2010). The characteristics of decision making, potential to take risks, and personality of college students with Internet addiction. Psychiatry Research, 175(1-2), 121-125. https://doi.org/10.1016/j.psychres.2008.10.004.

Mafimisebi, O., Obembe, D., Kolade, O., Obembe, F., Owoseni, A., \& Mafimisebi, O. (2021). Covid-19 and the tourism industry: An early stage sentiment analysis of the impact of social media and stakeholder communication. International Journal of Information Management Data Insights, 1(2). https://doi.org/10.1016/j.jjimei.2021.100040.

Miles, \& Huberman. (2007). Analisis Data Kualitatif. Universitas Inggris.

Musavengane, R., \& Kloppers, R. (2020). Social capital: An investment towards community resilience in the collaborative natural resources management of community-based tourism schemes. Tourism Management Perspectives, 34. https://doi.org/10.1016/j.tmp.2020.100654.

Paramita, I. B. G., \& Putra, I. G. G. P. A. (2020). New Normal Bagi Pariwisata Bali Di Masa Pandemi Covid 19. Jurnal Ilmiah Pariwisata Agama Dan Budaya, 5(2). https://doi.org/10.25078/pba.v5i2.1723.

Perles-Ribes, J. F., Ramón-Rodríguez, A. B., Sevilla-Jiménez, M., \& Moreno-Izquierdo, L. (2016). Unemployment effects of economic crises on hotel and residential tourism destinations: The case of Spain. Tourism Management, 54. https://doi.org/10.1016/j.tourman.2015.12.002.

Qiu, Y., \& Jiang, F. (2022). A review on passive and active strategies of enhancing the safety of lithium-ion batteries. International Journal of Heat and Mass Transfer, 184. https://doi.org/10.1016/j.ijheatmasstransfer.2021.122288.

Saad, S. K., \& Elshaer, I. A. (2017). Organizational Politics and Validity of Layoff Decisions: Mediating Role of Distributive Justice of Performance Appraisal. Journal of Hospitality Marketing and Management, 26(8). https://doi.org/10.1080/19368623.2017.1320257.

Shakerian, H., Dehnavi, H. D., \& Ghanad, S. B. (2016). The Implementation of the Hybrid Model SWOT-TOPSIS by Fuzzy Approach to Evaluate and Rank the Human Resources and Business Strategies in Organizations (Case Study: Road and Urban Development Organization in Yazd). Procedia - Social and Behavioral Sciences, 230. https://doi.org/10.1016/j.sbspro.2016.09.039.

Shane, S. (2009). Why encouraging more people to become entrepreneurs is bad public policy. Small Business Economics, 33(2). https://doi.org/10.1007/s11187-009-9215-5.

Sharabi, M., Polin, B., \& Yanay-Ventura, G. (2019). The effect of social and economic transitions on the meaning of work: A cross-sectional study among Israeli employees. Employee Relations, 41(4). https://doi.org/10.1108/ER-04-2018-0111.

Sharma, G. D., Thomas, A., \& Paul, J. (2021). Reviving tourism industry post-COVID-19: A resilience-based framework. Tourism Management Perspectives, 37. https://doi.org/10.1016/j.tmp.2020.100786.

Singh, A. L., Jamal, S., \& Ahmad, W. S. (2021). Impact assessment of lockdown amid COVID-19 pandemic on tourism industry of Kashmir Valley, India. Research in Globalization, 3. https://doi.org/10.1016/j.resglo.2021.100053.

Singhal, T. (2020). A Review of Coronavirus Disease-2019 (COVID-19). The Indian Journal of Pediatrics, 87(4), 281-286. https://doi.org/10.1007/s12098-020-03263-6.

Škare, M., Soriano, D. R., \& Porada-Rochoń, M. (2021). Impact of COVID-19 on the travel and tourism industry. Technological Forecasting and Social Change, 163. https://doi.org/10.1016/j.techfore.2020.120469.

Soliku, O., Kyiire, B., Mahama, A., \& Kubio, C. (2021). Tourism amid COVID-19 pandemic: impacts and implications for building resilience in the eco-tourism sector in Ghana's Savannah region. Heliyon, 7(9). https://doi.org/10.1016/j.heliyon.2021.e07892.

Tang, Y. M., Chen, P. C., Law, K. M. Y., Wu, C. H., Lau, Y., Guan, J., He, D., \& Ho, G. T. S. (2021). Comparative analysis of Student's live online learning readiness during the coronavirus (COVID-19) pandemic in the higher education sector. Computers \& Education, 168. https://doi.org/10.1016/j.compedu.2021.104211.

Utkarsh, \& Sigala, M. (2021). A bibliometric review of research on COVID-19 and tourism: Reflections for moving forward. Tourism Management Perspectives, 40. https://doi.org/10.1016/j.tmp.2021.100912.

Valdez, M. E., \& Richardson, J. (2013). Institutional determinants of macro-level entrepreneurship. Entrepreneurship: Theory and Practice, 37(5). https://doi.org/10.1111/etap.12000.

Wang, Y., Hong, A., Li, X., \& Gao, J. (2020). Marketing innovations during a global crisis: A study of China firms' response to COVID-19. Journal of Business Research, 116. 
https://doi.org/10.1016/j.jbusres.2020.05.029.

Williams, A. M., \& Baláž, V. (2015). Tourism Risk and Uncertainty: Theoretical Reflections. Journal of Travel Research, 54(3). https://doi.org/10.1177/0047287514523334.

Yang, Y., Zhang, C. X., \& Rickly, J. M. (2021). A review of early COVID-19 research in tourism: Launching the Annals of Tourism Research's Curated Collection on coronavirus and tourism. Annals of Tourism Research, 91. https://doi.org/10.1016/j.annals.2021.103313.

Yi, Y., Chen, Y., \& Li, D. (2022). Stakeholder ties, organizational learning, and business model innovation: A business ecosystem perspective.

Yin, J., \& Ni, Y. (2021). COVID-19 event strength, psychological safety, and avoidance coping behaviors for employees in the tourism industry. Journal of Hospitality and Tourism Management, 47. https://doi.org/10.1016/j.jhtm.2021.04.017. 